Virđinija Popović, Marina Puja Badesku

Filozofski fakultet Univerziteta u Novom Sadu
UDK 821.163.41-14.09 Dučić J. 821.135.1-14.09 Bacovia G. Originalan naučni rad

\title{
METAFORIČKE SLIKE U POEZIJI JOVANA DUČIĆA I ĐORĐA BAKOVIJE ${ }^{1}$
}

Jovan Dučić i Đorđe Bakovija su pesnici koji su doprineli formiranju modernog lika srpske i rumunske književnosti. Iako pripadaju različitim književnostima, u njihovim delima možemo uočiti mnogo sličnosti, u prvom redu misaonu produbljenost, jezgrovitost u izrazu, stvaranje novih simbola, igru bojama, obuzetost smrću i usamljenošću, praćenu bezgraničnom željom da se dokuči i protumači smisao života i življenja. U pesmama Dučića i Bakovije opisi prirode bivaju dekonkretizovani, unutrašnji prostori se sužavaju, smanjuje se udeo ne samo deskriptivnih nego i emocionalnih elemenata, a pojačava se udeo misli i simbola. Đorđe Bakovija je preteča rumunskog modernizma, kao što je u srpskoj književnosti Jovan Dučić. Rumunska kritika ga svrstava među najveće nacionalne pesnike između dva svetska rata, zajedno sa Tudorom Argezijem, Lučijanom Blagom i Jonom Barbuom.

Ključne reči: metafore, boje, simbol, smrt, usamljenost, priroda, kiša, razgradnja materije

Rumunski i srpski narod su vekovima bili vezani korektnim dobrosusedskim odnosima, a njihova međusobna saradnja traje i danas. Upućeni jedni na druge, često su kontaktirali i komunicirali na svim životnim nivoima, od politike, istorije, ekonomije, preko kulture, do književnosti. U svom književnom stvaralaštvu i srpski i rumunski književnici ugledali su se na evropske kolege, trudeći se da što više prate evropske tendencije. Praćenje evropskih književnih struja postaće najuočljivije krajem XIX i početkom XX veka, kada u svetskoj književnosti nastupa period moderne književnosti. Iako su pratili evropske tendencije, i u srpskoj i u rumunskoj književnosti postoje pojedinci koji su svojim stvaralaštvom doneli nešto samosvojno i novo. Ovaj rad je posvećen predstavljanju dva pesnika koji pripadaju različitim književnostima (srpskoj i rumunskoj), ali koje vezuje bezgranična ljubav prema pesmi. Na poetičkom planu Dučiću i Bakoviji blisko je nastojanje da svojim delima doprinesu književnosti, da je dignu na viši estetski nivo tako što će čitaocima najpre predstaviti svoje unutrašnje svetove, a potom i dočarati sopstveno shvatanje i viđenje realnosti (sveta) koja ih okružuje.

Jovan Dučić i Đorđe Bakovija² doprineli su formiranju modernog lika srpske i rumunske književnosti, u saglasnosti s poetičkim momentom tadašnje evropske

1 virginiapopovic@yahoo.com

2 Ovaj rad je realizovan u okviru projekta Jezici i kulture u vremenu i prostoru, br. projekta 178002, finansiran od strane Ministarstva prosvete i nauke Republike Srbije. 
književnosti. Iako pripadaju različitim književnostima, u njihovim delima možemo uočiti mnogo sličnosti, $u$ prvom redu misaonu produbljenost, jezgrovitost $\mathrm{u}$ izrazu, stvaranje novih simbola, igru bojama, obuzetost smrću i usamljenošću, praćenu bezgraničnom željom da se dokuči i protumači smisao života i življenja. I Dučić i Bakovija su u svojim pesmama obrađivali različite teme, ali njihovo stvaralaštvo ipak dostiže vrhunac u pesmama prirode. Njihov stvaralački put ide od deskriptivnog ka misaono-simboličkom načelu. U njihovim pesmama se opisi prirode dekonkretizuju, unutrašnji prostori se sužavaju, smanjuje se udeo ne samo deskriptivnih nego i emocionalnih elemenata, a pojačava uloga misli i simbola. U ovom radu, imajući u vidu širinu i slojevitost pesničkih opusa Dučića i Bakovije, bavimo se pre svega dominantnim motivima smrti i usamljenosti, a potom simbolikom boja i poetskog doživljaja prirode. Pokušavamo da pronađemo sličnosti i razlike tumačeći njihove jedinstvene i nesvakidašnje mikrokosmose, kao i da približimo čitalačkoj publici njihova shvatanja o najvećim i najfatalnijim motivima života i umetnosti.

Đorđe Bakovija i Jovan Dučić svojim stvaralaštvom tragaju za smislom u svetu u kojem smisao nije nužan. Oni su pesnici koji su težili pogledu u svet onostranosti. Čitalac koji nema predispozicija za prihvatanje totaliteta postojećeg, niti sposobnost za iskorak izvan puke očevidnosti realiteta neće biti u stanju da se približi poeziji Dučića i Bakovije. Nesvakidašnji i neponovljivi u svom književnom izrazu, ovi pesnici su obavezujući za nove generacije pesnika u obe zemlje, jer se njihov jezik, jezik umetnosti, može razumeti jedino ukoliko se recipijent, podstaknut čitanjem stihova, prepusti sopstvenoj spoznaji sveta oko sebe i neobičnoj igri boja i simbola. Jovan Dučić je jedan od najproduktivnijih i najčitanijih srpskih pesnika, „lucidnog intelekta i budnih čula, cerebralan i meditativan pesnik, u koga nema osećanja koje nije proceđeno kroz sito razmišljanja, i za koga je zakon proporcije glavni zakon misli, Jovan Dučić je naslednik klasičara, ne romantičara. U njega ima i mudrosti, i spokojstva, i poleta i žara. On je retko uzbuđen kad što doživi ili vidi, ili kad što otkrije, i zato retko uzbuđuje i čitaoca. Njega zasenjuju boje, zanose zvuci, zavode žene, odvode u davninu prošli dani i on, ozaren i zadivljen, zasenjuje i zadivljuje druge, ali ih ne zanosi i ne očarava" 32 . U svom stvaralaštvu Dučić se ugledao na francuske drugorazredne pesnike (po mišljenju današnjih kritičara). U rumunskoj književnosti simbolizam nastaje kao odjek francuskog simbolizma, a njegov začetnik je upravo Đorđe Bakovija. Magični simbolizam se dovodi u vezu sa planetom Saturn i sa olovom (kao metalom), sumporom (kao mirisom) i žutilom kao bojom. Objavljivanjem prve zbirke pesama Plumb / Olovo (1916) Bakovija je pokazao u kojoj meri su na njegovo stvaralaštvo uticali francuski pesnici, poput Bodlera i Verlena, a što se ogleda već u prvom stihu publikovanom 1915. godine: „Slika namirisana ljubičastim uzbuđenjem”.

Đorđe Bakovija (George Bacovia) rođen je 1881. godine u gradu Bakau u Rumuniji. Godine 1903. završio je gimnaziju u Bakau i upisao prava u Bukureštu. Prvu zbirku peama Plumb (Olovo) objavio je 1916. godine. Ostale zbirke pesama: Scântei galbene (Žute varnice, 1926), Bucăţi de noapte (Noćni komadi, 1926), Cu voi (Sa vama, 1930), Comedii în fond (U stvari komedije, 1936), Stanţe burgheze (Buržujske stance, 1946). http://srcekrajine.net/diskusije/index.php?topic=128.0 
Dučićevo stvaralaštvo je mnogo složenije nego što se na prvi pogled čini. Dučić je pesnik koji se u svojim pesmama bavi raznorodnim temama. On spaja različite svetove i integriše ih u jednu celinu. „Njegovi simboli predstavljaju ponekad prave lične i ljudske drame, plastika njegovih opisa prirode slaže se u jedan poseban svet, rustičan i metafizičan u isti mah, u kome se otvaraju autentični prostori za opstanak mašte" (M. Pavlović, Osam pesnika, 12). Dučić je nesporno pesnik velike umetničke discipline, on je umeo da iskaže nagoveštaj i sugestiju složenih duševnih stanja i skrivenih misaonih procesa. Koristeći poseban vid metafore Dučić je pokazao koliko je za njega ona moćno izražajno lirsko sredstvo.

Bakovijin lirizam je „osujećen napor univerzalnog i izjednačanog artikulisanja pesme, uzaludnog depoetisanja. On je pesnik 'večne beskonačnosti', nesposoban da više otkriva smisao. Njegov svet predstavlja življenje bez života, a ljudske drame se igraju na sceni života, postajući tragične ili apsurdne" (G. Grigurcu. Bacovia - un antisentimental: 5). Bolešljive prirode, duboko tragičnog senzibiliteta, pesnik se zatvara u ograničen prostor opsesivno shvaćene prirode, u kojem, gotovo fatalističkim ponavljanjem, ,svi elementi dobijaju iskonsku funkcionalnost simbola" (Puslojić 1978: 9-10). Svet koji ga okružuje, ,,zatvoren šarkama” izazvaće njegove grozničave košmare, koji će se preneti i na njegovu poeziju. Sa ove tačke gledišta, Bakovija ne samo da je jedan od najvećih rumunskih modernista već je i najradikalniji među njima. S druge strane, Dučićeva poezija nastaje u ključu kasnog simbolizma sa očuvanom parnasovskom prozodijom. Njegov stih je ekspresivan, slikovit, logičan i ispunjen različitim tonovima. On nikad ne luta za smislom, već što u jednom stihu nagovesti u drugom i ostvari. Dučićev stih je individualan i jedinstven u srpskoj poeziji. Snaga i originalnost njegove poezije su u izražaju, ona blešti slikovitošću i haotičnim ritmom koji oslikava pesnikov doživljaj stvarnosti, pri čemu prikazuje njegov unutrašnji kosmos koji se umnogome razlikuje od sveta koji ga okružuje. Kod Bakovije se kao i kod Bodlera, Remboa i ostalih francuskih simbolista, primećuju apstraktne, opšte filozofske teme. One su na poseban način uspostavile relacije, njihova suština je u izrazito individualnom odnosu. Presudne su, i naglašene, najhitnije odlike u četiri odnosa: pesnikov odnos prema prirodi, prema životu, u odnosu prema drugim ljudima, kao i pesnikov odnos prema smrti. Bakovija insinuira da umetnost nastaje u tamnom vrtlogu življenja kroz projekciju sopstvenog doživljaja stvarnosti. Pesnik stvara jer ne može da to ne čini, jer time olakšava svoje bivstvovanje u „haotičnom i olovnom svetu”. Nenadmašna je energija koja ga tera da čini upravo to i ništa drugo. On poput pauka ispreda iz svojih grudi, iz srca, iz bolnog maglovitog sna mrežu koja spaja nebeske visine i zemaljske doline i, paradoksalno, postaje zamka za druge. U Bakovijinoj poeziji se prepoznaju i neki opšti motivi koji su svojstveni i za Dučića, ali i za francuske simboliste: cveće, ptice koje su oličenje prolaznosti, kobi, teskobe, kao i boje koje doprinose sveopštem utisku i doživljaju njegove poezije. Dučićeva poetika, kao i Bakovijina, u celini ima jasnu strukturu i u njoj sve kao da teče, odnosno, slike se nastavljaju iz jedne strofe u drugu. Dučić je u frazeologiji i u leksici izbegavao hrapave i grube reči, kao i suviše konkretne predmete i situacije. 
Celokupno stvaralaštvo Jovana Dučića, na osnovu tema kojima se bavi u svojim pesmama, može se podeliti na šest opsesivnih tema (Bog, žena/ljubav, otadžbina, priroda i poezija). Tema smrti je jedna od najdominantnijih i najupečatljivijih tema u Dučićevoj poeziji pored teme Boga i prirode. Čak i u prve dve Dučićeve knjige Pesme sunca i Pesme ljubavi i smrti nalazi se trideset i pet pesama sa temom smrti. Kada govori o temi smrti, Dučić podseća na Bakoviju, jer oni sebe postavljaju na granicu između svetova - sveta živih i sveta mrtvih i to predstavlja jednu od najvećih i najtrajnijih fascinacija u njihovoj lirici. Zahvaljujući motivu ,granice između večnog i trenutka", između smrtnosti i večnosti, Dučićeve pesme dobijaju na vrednosti, jer njihova dubina i misaonost sprečavaju da pesme postanu previše sentimentalne i srceparajuće.

Što se tiče teme smrti u poeziji Bakovije, ona je mnogo izraženija i upečatljivija nego kod Dučića. Ona je lajtmotiv koji prožima gotovo sve njegove pesme. Dok za Dučića smrt predstavlja samo način da se još više približimo Tvorcu, ona za Bakoviju ima sasvim drugu konotaciju. Za njega smrt nije samo jedna etapa, za njega je čitav život smrt, on je opsednut motivom smrti. On u svemu vidi smrt, njega smrt okružuje i svakim danom ga sve više guši. Za njega smrt nije skraćivanje ovozemaljskih muka, već ona predstavlja jednu sasvim novu sferu u kojoj čovek pati u još većim mukama nego dok je bio živ. On u svojoj poeziji sebe vidi u sanduku i dočarava kako ga jedu crvi: „Duboko su spavali olovni kovčezi, / I cveće od olova i pogrebno odelo - / Sam sam u grobnici... beše vetar to... / Škripali su venci olovni" (Olovo, str. 14). Za njega je smrt teška, bolna, olovna. Vasiona plače u rasulu, ljudski svet propada dotaknut truljenjem. Njegov sanduk je masivan, težak i olovan. Čak mu ni zemlja u koju ga spuštaju ne olakšava muke, već ga je i ona pritisnula svom svojom težinom, a njena oker žuta boja odaje utisak jedne bolesne, teške i zagađene zemlje. Kod Bakovije su motiv smrti i groblja veoma usko povezani, gotovo nerazdvojivi. Bakovijini opisi groblja su veoma subjektivni, prožeti određenom dozom strave i užasa. Groblje preleću samo crni gavranovi i lešinari. Ljubav je kod njega takođe povezana sa mrtvima, sa osećanjem raspadanja materije i truleži: „Živi se miču, i sami raspadnuti / Kao glina toplotom ovlažena, / Miris leševa se oseća, voljena ti, / Danas su i tvoja nedra malo uvela" (Jul, 14). Za razliku od Bakovije, Dučić je u svojim opisima mnogo blaži. I kod Dučića se pojavljuje motiv groblja u pesmi U sumraku - gde se iz čovekove svesti o konačnosti javlja egzistencijalni nemir koji je propraćen nizom statičnih slika kao što su „nebeske širine”, „kapele stare” (Popović 2009: 359). Najbliža temi smrti je, ipak, pesma Zavet koja prikazuje veliku bliskost i odnos između lirskog subjekta i Tvorca. Pesma prikazuje obraćanje Tvorca lirskom subjektu, ali i ljudima uopšte. On govori o čovekovoj poziciji i situaciji na zemlji i njegovom odnosu prema Bogu. Dučić se u pesmi trudi da prikaže paradoksalnost odnosa Boga i čoveka. U pesmama o Bogu i smrti stalno prikazuje vezu između čoveka i Boga, koja je prožeta motivom smrti, pri čemu ,prelazak ljudskog tela u prah i ponovno sjedinjavanje sa zemljom nije pad u ništavilo, vać miran povratak Tvorcu" (Delić, 2009: 154). U pesmi Lirika približavanje Bogu jedino je moguće prelaskom „u grumen gline 
užežene”: „Kad moj prah, Tvorče, mirno pređe / U grumen gline užežene, / Tad neće više biti međe / Između tebe i između mene" (Ibidem: 90). Ovom pesmom Dučić ulazi u sfere metafizičkog, onostranog i uvodi pitanje o postojanju Boga, njegovim preobražajima i sopstvenim sumnjama.

U Bakovijinom pesništvu preovlađuje težnja da se dokuči ono bitno, suštinsko po čoveka i njegov opstanak. Večna pitanja i veliki problemi predstavljaju tematsku okosnicu gotovo svih njegovih pesama: čovek - priroda, obesmišljenost realiteta i spasonosna delatnost poezije, neminovnost smrti i neophodnost traganja za smislom življenja, sve su to ključne teme na osnovu kojih se i smatralo da je Bakovija misaon, filozofski pesnik. Njegova poezija se prisno vezuje sa mislima, zbog čega je za njeno razumevanje potrebno posedovati izvesno metafizičko čulo. Ko nema osećaja za totalitet postojećeg i ko nema sposobnost za iskoračenje izvan puke očevidnosti realiteta neće biti u stanju da se približi ovoj poeziji. U Bakovijinoj poetskoj slici sveta čvrsto je ugrađeno osećanje sumnje. Njegova smislotvornost se, dakle, realizuje kao iskaz o poteškoćama konstituisanja smisla u jednom svetu koji je Bog prepustio samom sebi, da se on, taj svet, snalazi kako zna i ume. Bakovijin pesnički prostor ispunjen je sumrakom, kišom, noćima, zimom i jesenima, a kao pečat po svemu tome - „turobna muzika i zlokobna ljubičasta boja” (Puslojić 1978: 10). Otuda ni oni ključni entiteti, kao što su priroda, onostranost, smrt, strah neće biti pošteđeni dvostrukosti viđenja, pri čemu kod Bakovije preovlađuju one tamne i negativne strane. Bakovija je pesnik teškog, mučnog probijanja do smisla: on je pesnik metodske sumnje. Kao i Bakovija, Dučić u pesmama u kojima se koristi motivom smrti uspeva da prikaže sugestivnost, višeznačnost i metafizički svet.

Kada se govori o Dučićevoj i Bakovijinoj poeziji i njihovom stvaralaštvu uopšte, ne može se posmatrati samo jedan segment njihovog opusa, već je potrebno sagledati njihovo stvaralaštvo sa jedne više rezonance kako bi se imao pregled $\mathrm{i}$ jedinstvena slika čitavog njihovog tematskog područja. Na početku svog stvaralaštva Dučić se bavio prirodom, koja je bila centar i osnovni motiv njegovih prvih pesama. Da bi se razumela njegova poezija prirode, mora se krenuti od samog početka, od njegovih najranijih ostvarenja kao što je pesma „Zalazak sunca”. Jedinstvene Dučićeve metafore koje govore o njegovom doživljaju prirode (bakreno nebo, crvena reka, smaragdne gore, bleda kao čežnja, nebo zlatno, silna kao samrt...), prvi put su tada viđene u srpskoj poeziji. Dučić se i u kasnijem stvaralaštvu služi ovim metaforama, a „senzacije boje i zvuka koje je on doneo bile su prvi početak velikih namera" (Dučić 1989: 114) u srpskoj lirici. Ove obojene i čulne metafore koje su prvi put napisane u Zalasku sunca predstavljaju lirski preobražaj Dučićevog doživljaja prirode. On u ovoj pesmi otkriva široke prostore prirode i svemira. Za Dučića je priroda jedan ciklus, krug u kojem se sve smenjuje i nadovezuje jedno na drugo. Dučićeve pesme odišu upotrebom reči iz svakodnevnog govora (koje nisu u tolikoj pesničkoj upotrebi) „pada mrak”, ,sunce gasne”, a onda njihov tok iznenada prekidaju neočekivane slike „,buktinje”, „ognja”, ,požara", koje otvaraju mogućnosti za prikazivanje impozantnih pesnikovih doživljaja 
prirode, kao što su „bakarno nebo”, „crvena reka”, „,bleda kao čežnja”. Dučić svojim metaforičnim slikama stvara novi svet u kojem se niz vizuelnih doživljaja preliva u auditivne doživljaje koji žive u svetu novog koncepta vremena i prostora. Da bi sve ovo što verodostojnije prikazao, pesnik se pored metafore služi i kontrastom kao stilskom figurom. Kontrast ima za cilj da objasni i prikaže prirodne cikluse kao što su „sjaj” i „blesak” nakon kojih se javljaju „mrak” i „tama”, ali i da prikaže prolaznost vremena i promenljivost i neuhvatljivost svakog momenta koji neumitno prolazi. S druge strane, Bakovija se nameće, po mišljenju kritike, kao pesnik moderne rumunske književnosti. Po formaciji simbolista, Bakovija premašuje epohu, postavljajući modernu rumunsku književnost među jednu od najvećih struja u književnosti uopšte. Bakovija je dekadentni duh osećajnosti koja se izražava kroz umerenu esencijalnost (Fanache 1994: 174). Za Bakoviju priroda predstavlja izraz neorganizovane duše, odraz nervoze. Njegova priroda je prožeta raspadanjem i u stalnom je dodiru sa sporom smrću. Kod njega je priroda neprijateljska, mučna kao tamnica: „Gvozdene kuće okovane zidovima, / I strašna vrata se zaključavaju” ili „Dveće belo, drveće crno / Golo u samotnom parku: / Pogrebni, žalosni dekor... / Drveće belo, drveće crno." (Dekor, str. 17) Bakovijine odaje su hladne i negostoprimljive, u uglu ,spavaju crne senke”, vatra treperi u ogledalu, a slike na zidovima vise tužne i iskrivljene.

Po ugledu na verlenovski simbolizam, parkovi, cveće i fontane su kod Bakovije tvrdi, kruti i oporni, a u isto vreme i toliko nestabilni kao da su od hartije, pri čemu odišu otrovnim mirisima. U Bakovijinoj poeziji nervoze se ispoljavaju kroz ,vlažne i prljave krčme" ili kroz mračne prostorije ispunjene duvanskim dimom i parom. Bakovija je u svom stvaralaštvu motive crpeo iz okolnog eksterijera, sa određenom dozom distance pri čemu se neprimetno kretao od ironije ka parodiji: „Ima nekoliko mrtvih u gradu, voljena, / a leševi se polako raspadaju...” (Jul, str.16). Oba pesnika u svojim pesmama prepliću vizuelne i zvučne metafore, mada je princip upotrebe u oba slučaja isti. Ako obratimo pažnju na pesme pod naslovom Akordi i Tišina, videćemo da Dučić zvučnim metaforama oživljava pejzaž na veoma lirski način: „zvezde šušte”, ,pevaju sfere”, ,,vode huje”, „,vrbe šume” a čije čulno doživljavanje ispunjeno živopisnim koloritom doprinosi i određenoj dozi misticizma u Dučićevoj poeziji, što se takođe može sresti i kod Bakovije u pesmi Sojenica: „Već toliko noći čujem kiše / Čujem materiju kako plače...”. Personifikacija dočarava pesnikovo osećanje usamljenosti koje se „bledo ogleda u modrilu reke” kod Dučića, a kod Bakovije: ,od zaleđene krvi belina se zapalila” (Zimska slika, str. 15). „Krhkost u Bakovijinim pesmama izložena je bez poštede kosmičkim promenama i njeno poetsko biće teži neposrednoj zaštiti, koju organizuju tanane, nedokučive materije" (G. Grigurcu, 1974). Strah od neizmernog i neprekidnog kolebanja, kao otrovno lepršanje, rasplamsava plamen Bakovijinog duha. Usamljenost pojačava halucinantnost, sugerišući jedno nepodnošljivo ćutanje: „Ništa. Usamljenost se čini sve veća... / I u gorkoj noći samo ćutanje cvili." (Ako ne) ili „Čujem kišu tolikih noći, / Sve čekajući, sve trzajući se... / Sam sam i misao me vodi / U stanove-sojenice... (Sojenica, str. 15). Pod teretom smrznutih zvezda pesnik 
se oseća tragično naježeno: „Brr!... Brr! ... udaljavam se od hladnih zvezda... / U užasnoj noći kome ćete kucati? (Zimsko olovo).

Kada govorimo o Dučićevoj poeziji prirode, zapaža se još jedna karakteristika, a to su boje, odnosno metaforičnost boja. Svoj doživljaj boja iz prirode kao i njihove promene Dučić veoma verno prenosi u svoje pesme, pri čemu dosledno sprovodi proces prenosa. Npr.: „bakarno nebo” iz pesme Zalazak sunca u stvari predstavlja smiraj dana, tj. zalazak sunca, a njegov odblesak na nebu stvara bakarne i krvave nijanse. Sve su boje kod Dučića sklone promenama i međusobno su veoma povezane, pa tako nebo pri smiraju dana nije više plavo, već postaje bakarno, crveno, krvavo, zatim modro i tako dok ne postane crno, tj. sve dok ne nastupi tama, noć. Gradacija doprinosi ritmičnosti pesama, pri čemu gotovo svaka pesma ima jedan svoj ciklus, odnosno početak i kraj (rađanje dana i sunca, pa sve do večeri kada nastupa tama). Gradacija pored ritmičnosti pesme doprinosi i njenom duhovnom kretanju, pri čemu se od konkretnog pejzaža prirode kreće ka jednom novom, apstraktnom pejzažu. Da bi se lakše protumačio Dučićev lirski pejzaž moramo, bar donekle, da shvatimo „njegovu velaskezovsku paletu, koja podstiče imaginaciju i proizvodi različite čulne i vizuelne utiske" (Popović 1989: 73). Kod Dučića ljubičasta boja predstavlja svaku tamnu nijansu. U njegovom stvaralaštvu tanke su granice među tamnim nijansama, ali su one gotovo uvek suprotstavljene svetlim nijansama. Simbolističke boje se kod Bakovije razlivaju kao zvukovi i mirisi, ispunjavajući njegove stihove interesantnim esencijalnim lirizmom. Za Bakoviju boje nisu samo trajne i opsesivne, već za njega one imaju veliku materijalnost, kao i kod ekspresionista. Kada govorimo o prikazivanju pejzaža, boje predstavljaju rušenje, unakaženost kao lice na kojem se razmazala šminka. Ljubičasta, crna, bela i crvena boja preplavljuju mesta kao neke fizičke prisutnosti, narušavajući pejzaž, čineći ga prljavim. Bakovija ne predstavlja realno svet oko sebe, već svoj doživljaj sveta, tj. ono ,izmaltretirano”. Prikazivanje „,izmaltretirane" stvarnosti je mehaničko ponavljanje kroz koje Bakovija stvara jedan marionetski svet voštanih lutaka koji pravi groteskne skokove kao neka neartikulisana stvorenja. Bakovija je u rumunskoj književnosti i kritici ostao upamćen po pojačanoj senzibilnosti (zvuka, boja ili kinetike), kao i po pojačanoj ekspresivnosti koja je dosegla nepodnošljive granice. Tragajući za elementarnim skloništem (,pećina odvajkad”), autor Olova pretvara primarni egzistencijalni podstrek u liriski ferment. Okolni pejzaž se širi, intimizira, prostirući se između nevidljivih zidova koji gotovo da guše: „Siva jesen / Agonija - iz srži - / Ptice lete / I tajnovito se kriju. / Rominja kiša... / Nikoga nema na ulici; / Napolju stojiš / I dim te mami" (Pastel). Boje u Bakovijinoj poeziji imaju značajnu ulogu jer doprinose vernom prikazivanju napetog psihološkog prostora pesnika. Njegova poezija je ispunjena optičkim doživljajima prirode i sveta koji ga okružuje i ona se nalazi u koincidenciji sa psihološkim aluzijama stvarajući plastične slike Bakovijinog sveta, koji je bio gotovo materijalno neopipljiv. Boje pojačavaju njegovu percepciju sveta i uvode nas u njegov mikrokosmos u kojem preovlađuju siva, žuta, bela, crna i ljubičasta boja: „S belim perjem, s crnim perjem / Ptica s gorkim glasom, / Preleti vekovni park... / S belim perjem, s crnim perjem..." (Dekor, str. 17) 
Prikaz Dučićevog i Bakovijinog pejzaža ne predstavlja samo puki pejzaž, već oni u središte prikazivanja stavljaju lični doživljaj, pri čemu realnom svetu, tj. svetu koji ih okružuje daju izgled sopstvene duše. Ovde se ogleda mešanje eksternog i internog, odnosno povezivanje unutrašnjeg i spoljašnjeg. Dučić želi da ukaže na smenu dana i noći, vidljivog i nevidljivog, stvarnog i imaginarnog, upućujući na postojanje Boga i uvodeći temu smrti kako bi prikazao motiv umiranja i rađanja u fenomenologiji prirode. Upravo se ova smena dana i noći, života i smrti, fizičkog i metafizičkog može posmatrati kao jedan od principa evropskog simbolizma, koji se prepoznaje u stvaralaštvu ova dva pesnika, pored uticaja parnasizma i predavangardnih tendencija. Poetika Jovana Dučića se može posmatrati kao „simbolična apotoeza lepote i mistične sudbine nerazdeljivog života i sveta, ali ne njihove suprotnosti, već njihovog nastavka" (Kašanin 2004: 235).

Za Bakoviju melanholija predstavlja ,jecaj jeseni”, poziv iz duboke zemlje. Jesen ispunjena agonijom ovim pozivom iz kišne zemlje asocira i na prigušen dim. Ljubičasta, poslednja boja u svetlosnom spektru, sugeriše suton koji se oslikava kroz tešku jesen. Pesnik kroz prirodu vidi svet koji iščezava. Za njega je jesen delirično godišnje doba, prepuno iracionalnih događaja. Bakovija obožava šemu kroz koju se vidi kako se materija razgrađuje na kiši, kako se pridružuje stranoj posmrtnoj koloni, kako ulazi u kafanu, zalazi u kuće, ruga se bez smisla, luta po ulicama, a onda odjednom veoma brzo nestaje. Ovalno ogledalo sa zlatnim ramom reflektuje gangrenski vrt, opustošen, sa mermernom masom ispunjenom odrom na kojem pesnik leži, smejući se i svirajući na klaviru posmrtni marš. Opalost, opustošenost vegetacije, balans drveća na vetru prikazuje gubljenje moralne ravnoteže. Lišće „kao zloslutan znak” ubrzava ljubavne scene. Neprestana kiša, simbol razgradnje materije i hibernalna zavejanost predstavlja ideju iščeznuća kroz razrušenu strukturu stvari koja je ostvaruje kroz belu i crnu boju. Zavejani park, crna i bela boja za Bakoviju predstavlja dekor sahrane. Alhemičari su povezali mesec sa zlatom, stoga smrznuti vašar „kao prostran tepih” razvija jedan novi smisao zlata. Ispod strašnog olovnog horizonta težak pepeljasti sneg je strašna slutnja. Belo polje sa kristalnim drvećem je neizmeran krug dijametralno pocepan od strane jednog gavrana. Hladna umrtvljenost svakog sna daje osećaj iscrpljenosti, ali i čudne tromosti i malaksalosti jednog ostavljanja. Asocijacije su suptilne, „,prljav sneg”, umazan, projektujući pesnikovu senku u blatu, kao bela ruža u čaši. Kod Bakovije se retko javlja proleće, godišnje doba mladosti, nevinosti, čistote i snova kojima odgovaraju ,gruba zelena”, crvena i bela boja. U stvari, leto je godišnje doba raspadanja, pogađajući zapravo materiju života i provocirajući erupciju krvi, bledila.

U stihovima oba pesnika oblici i boje se prepliću, a različite slike se jedna na drugu preslikavaju. Glavne pesničke slike su jesenji i noćni pejzaži, opisani kroz ambleme prizora mrtvila i utihnuća prirode. Dučićeva jesen i priroda su veoma teške i sive, a nebo je predstavljeno kroz „pusta polja”, ,smrznute ledine”, ,mrtve šume". U njegovim prikazima prirode dolazi do mešanja utisaka i zapažanja, pri čemu se stvaraju prilično mutne slike. I on, kao i Bakovija i francuski simbolisti, 
asocijativno i slobodno povezuje perceptivni doživljaj prirode sa unutrašnjim raspoloženjima.

U mnogim pesmama se pojavljuje sumrak, suton, zalazak kao sugestija bliskog kraja, odakle i opsesija crnim pticama i gavranima kod Đorđa Bakovije. Sumrak je bolestan, plače sa prodornim crnim lišćem kroz okno, okrvavljujući jezero, crveneći maramice od lišća. Ljubičasta je boja žalosti i tuge. Mesec se pojavljuje u ljubičastom šumarku grada a pesnik ga vidi ,pomodrelog kao leš”, suton stvara boje od zlata, krvi koje se ogledaju u vodopadu i lakiranim pločicama u parku i na spomenicima. Sumrak je „glinen” sa vetrovitim „posmrtnim orkestrom”, a sumorna i metalna zima sa očajnim vapajem i nesnosno leto nagoveštavaju, reklo bi se, požar sličan onom u Sodomi i Gomori. Sposobnost Bakovijinog življenja i simbolizovanja osećanja, nemira, strepnji i nepoznatih strahova izvanredna je i naročita, kao i njegovo pronalaženje originalnih i neospornih modela u okviru rumunske književnosti. Centralna tema njegove poezije je usamljenost, koju nije stvorio pesnik, već neprijateljski neprihvatljiv svet u kojem vladaju neprirodna averzija prema svemu i indiferentnost prema svakome: „Sve više ćutljiv i sam / U mom pustom svetu / I sve više me sve pritiska / Strašna mizantropija”. Saputnik sa nakaznim osmehom i senkom luta noću kao pas pustim koracima ili sam u kući kada pada kiša ili sneg sluša kroz okno graktanje gavranova, pritisnut crnim mislima. Pomračenog uma, prepun tame i pustoši pesnik je ispunjen delirijumom.

Kao jedna od glavnih relacija Bakovijine i Dučićeve poezije jeste postavljanje Čoveka naspram prirode. To sučeljavanje budi nemir, slutnju i strahove. U središtu pesama nalaze se čovek i priroda, a čovek stoji, posmatra i - strepi. Simbolično prikazivanje prirode i realnosti uopšte predstavlja simboličnu manifestaciju opažanja i doživljaja lirskog subjekta, njegovih misli i strahova. Ideja usamljenosti prožima određen broj Dučićevih pesama, među kojima se izdvajaju Seme, Bogu i Tajna. U pesmi Seme govori se o semenu kedra koje simbolično predstavlja usamljenog pesnika - „stranca u svetu i gori”: „A kao pesnik, ti ćeš biti / Stranac u svetu i gori: / Od osama se što ushiti, / Od hladnih zvezda što sagori”. Na ovaj način motiv stranca, odnosno pesnika - usamljenog i otuđenog u svom telu i svetu uopšte, obuhvata veliki deo Dučićevog stvaralaštva. Stranac kao motiv jedna je od njegovih važnijih metafizičkih tema koja kroz strepnju i strah prelazi u pesimizam Kamijevog stranca, koji je usamljen i koji teži da spozna samog sebe. Bakovijina melanholija metafizička je vizija ništavila, pesnička aproksimacija smrti, percepcija neumoljivog kretanja univerzuma ka ljubičastom (,ljubičasta agonija”), ka dubokoj praznini i ledenom Tanasosu. U svojoj poeziji, kako kaže rumunski kritičar Jon Simuc, Bakovija uči da umire. Za razliku od njega, Dučić traži trijumf u životu, a ne u smrti, ,on pokušava da izađe iz samoće, oslobodi se tamnice života i porekne smrt. U njega je besna želja za lepotama, ljubavima, uživanjima, pobedama - on bez prestanka peva himne svetlosti i letenju. Ne nalazeći zadovoljenja u stvarnosti, on ga traži u snovima i himerama, u razgovoru sa prirodom i druženju sa nestalim svetom, u ogorčenoj težnji za nepropadljivošću i večnim trajanjem" (Kašanin 1968). 
Pojedini književni kritičari: Vladimir Streinu, Perpesičus, Pompilju Konstantinesku, Tudor Vjanu, Šerban Čokulesku, Bakoviju su najpre klasifikovali kao simbolistu, ali kasniji radovi su pokazali da se on pre može svrstati među rumunske moderniste. Iako je njegova prva zbirka pesama Plumb obeležena uticajem simbolizma, kasniji Bakovijini radovi, kao što su Scântei galbene, pokazuju da je otkrio moderniji pesnički koncept, bliskiji prozno-poetskom stilu nego klasičnoj formi stiha XIX veka. Međuratni kritičari vide Bakoviju ili kao neosimbolistu (Đorđe Kalinesku) ili kao osrednjeg pesnika sa manjkom inspiracije (Euđen Lovinesku). Međutim, nakon II svetskog rata njegova poezija biva povezana sa novijim strujama. Neki su je uporedili i sa pozorištem apsurda (M. Petroveanu), poetskim modernizmom, nadrealizmom, automatskim pisanjem, imaginarizmom, ekspresionizmom, pa čak i sa egzistencijalizmom (Jon Karajon). Upravo su ove karakteristike njegovog stvaralaštva omogućile da postane jedan od najznačajnijih rumunskih stvaralaca, poeta koji je uspeo da se izdigne iznad osrednjeg pesnika i da se uvrsti među klasike. S druge strane, Jovan Dučić je pesnik visokog stila i erudicije, koji predstavlja epohu na razmeđi ranog modernizma i pojave avangarde u srpskoj književnosti između dva rata. On je ostao u srpskoj književnosti kao prefinjeni simbolista, majstor stiha i elegancije. U srpsku poeziju je uneo jedan potpuno nov odnos prema životu i svetu, visoko je uzdigao i razvio motiv ljubavi, koji jednom delom obuhvata ženu, a drugim prirodu, stalan i najsadržajniji motiv Dučićevog pesništva.

\section{LITERATURA}

Bakovija, Đ. (1994). Opere. Bukurešt: Editura Fundaţiei Culturale Române.

Dučić, J. (1989). „Borisav Stanković”, Moji saputnici. Sabrana dela Jovana Dučića, knj. IV, Beograd - Sarajevo.

Dučić, J. (2006). Jovan Dučić. Sabrana dela. Knjiga 1. Valjevo: Parnas Book DLM.

Fanache, V. (1994). Bacovia ruptura de utopia romantică. Bucureşti: Editura Dacia.

Grigurcu, G. (1974). Bacovia - un antisentimental. Bucureşti: Albatros.

Kašanin, M. (2004). „Usamljenik Jovan Dučić” u: Sudbine i ljudi. Ogledi o srpskim piscima.

Beograd: Zavod za udžbenike i nastavna sredstva.

Krdu, P. (1991). Savremena rumunska poezija. Novi Sad: IP Svetovi.

Popović, B. (1989). O Dučićevom pesništvu, O Jovanu Dučiću. Sabrana dela Jovana Dučića, knj. VI, Beograd - Sarajevo.

Puslojić, A. (1978). Antologija savremene rumunske poezije. Sarajevo: Svijetlost.

Šeatović - Dimitrijević, S. (2009). Metafizički ciklusi u poeziji Jovana Dučića. U: Poezija i poetika Jovana Dučića, zbornik radova, Beograd - Trebinje. 
Virđinija Popović, Marina Puja Badesku

\title{
METAPHORICAL IMAGES IN THE POETRY OF JOVAN DUČIĆ AND GEORGE BACOVIA
}

\begin{abstract}
SUMMARY
Jovan Dučić and George Bacovia are modern poets who have influenced the Serbian and Romanian literature. Although they belong to different literatures, many similarities can be seen in their works: reflective profoundness, conciseness of expression, creation of new symbols, play of colours, preoccupation with death and loneliness and a boundless desire to grasp and interpret the meaning of life and living. In their poems the descriptions of nature are being deconcretized and interior spaces are being narrowed, reducing the share of descriptive and emotional elements and increasing the share of thoughts and symbols. In a similar way to Dučić's role in Serbian poetry, Bacovia is said to be the precursor of Romanian Modernism. Romanian criticism places him among the greatest national poets between the two world wars, alongside Tudor Arghezi, Lucian Blaga and Ion Barbu.

Key words: metaphors, colour, symbol, death, loneliness, nature, rain, degradation of matter
\end{abstract}

